\title{
The Implication of the 2011 General Elections on Democracy and Good Governance in Nigeria.
}

\author{
Chris Iwejuo Nwagboso \\ Lecturer Ii \\ Department Of Public Administration \\ University Of Calabar, Calabar-Nigeria. \\ Otu Duke \\ Assistant Lecturer \\ Department Of Public Administration \\ University Of Calabar, Calabar-Nigeria.
}

\begin{abstract}
This paper discusses the implication of the 2011 general elections on democracy and good governance in Nigeria using descriptive method as a mode of analysis. The paper attempts a critical discourse of how the abysmal failures of the stakeholders in the 2011 general elections in Nigeria like the INEC, political parties, security agents and the media, to administer credible elections would affect democracy and good governance in Nigeria. Thus, secondary data such as library research, newspaper articles and internet retrievals were used in this investigation. The results of the analyses revealed that the 2011 general election were flawed, due to compromise among the major stakeholders. The paper further argues that although the conduct of the 2011 general elections was comparatively better than the previous elections conducted in Nigeria such as 1999, 2003, and 2007, the election fraud and rigging in the 2011 general elections were mostly prevalent during the Governorship and State Assembly elections, particularly in the South-East and South-South geo-political zones of Nigeria. Therefore, the paper recommends among others, the adoption of electronic voting system, credible party primaries by political parties by the INEC as critical steps to restore sanity in Nigeria's electoral process.
\end{abstract}

Key Words: Election, Democracy, Good governance

\section{INTRODUCTION}

Election is considered as an indispensable ingredient of democracy in the contemporary world. Thus, it is viewed as the process of choosing a person or group of people for a political position. However, this process which requires mass participation of the citizens of the state is usually carried out by voting in a democratic and civilized world.

In Nigeria, the history of election dates back to 1923 (Duru and Nwagboso, 2005). However, the first election in the annals of the political history of the entity, now referred to as Nigeria was conducted as a result of the entrenchment of elective principle in the Macpherson Constitution of 1922. Thus, between 1923 and 2011, Nigeria has conducted several elections. These elections were ultimately held to enthrone democracy and to achieve good governance in Nigeria

Sadly, these elections were alleged to have been bedeviled with allegations of frauds, agitations, consternations and crises. Hence, the Nigeria's electoral history and the quest for enthronement of democracy have not been rosy. This pathetic situation seems to have not only 
adversely affected the growth of democracy, but also good governance in Nigeria. However, the 1999, 2003 and 2007 general elections were alleged to have been characterized by various forms of electoral malpractices and consequent agitations by the opposition parties. This ugly trend has been put in clear perspective by Ugah (2011) that:

...Certain political parties and politicians, most especially within the opposition group, have alleged many irregularities which negatively affected a free and fairness of the exercise...(This day Newspaper, p.10).

Thus, before the enthronement of democracy in 1999, other elections conducted prior to independence in Nigeria were also hotly disputed by political parties. According to PM News (May 17, 2011), the only election that was not seriously disputed before it was dictatorially annulled by the military junta headed by General Ibrahim Babangida was the 1993 presidential election.

Indeed, the 2011 general elections which kicked-off on April 9, 2011 with the National Assembly election has attracted mixed feelings among Nigerians. To some, the 2011 general elections was free, fair and credible, while others argue that the said election was akin to others held before it. According to Alao (2011: 15), "the 2011 general elections will go down as the most free and fair election in the history of Nigeria. Similarly, the international and domestic observers, including the Nigerian Labour Congress (NLC) and Trade Union Congress (TUC), have publicly lauded the 2011 general elections as truly free and fair.

Contrarily, some people have argued that the 2011 general elections was marred by irregularities. To them, this election is the most monetized election so far in Nigeria's electoral history. This view is supported by an Organization known as the Civil Society Election Situation Room which argues that:

Only candidates sponsored by parties already in power or candidates that have access to looted funds and or supported by the super-rich were able to win elections across the country and across parties... the ruling party at the centre, the PDP, despite having little or nothing to positively show for its control of power in 12 years and despite huge crude oil money that has accrued to Nigeria during this period... is still in control in Nigeria (www.socialistnigeria.org)

Notwithstanding these arguments over the outcome of the 2011general elections, the fact remains that this election was aimed as restoring sanity in the Nigeria's electoral process. Also, the Stakeholders - the INEC, Political Parties, Security agents, the Media, the Civil Society organizations, among others, agreed to play the 'electoral football' during the 2011 general elections according to the rules and regulation enshrined in the 1999 constitution and amended 2010 Electoral Act of Nigeria. Unfortunately, available evidence appears contrary.

In consideration of this, this paper attempts a critical exposition of the implication of the 2011 general elections in Nigeria. The paper examines the extent to which the outcome of 2011 general elections could impact positively or negatively on democracy and good governance in Nigeria. This is against the backdrop of the fact that a free, fair and credible election is expected to usher in rapid socio-economic development in the country and further paves away to efficient service delivery to the citizens. 


\section{THEORETICAL FRAMEWORK}

This paper adopts goal-setting theory and structural - functional approach in the analysis of the implication of the 2011 general elections on democracy and good governance in Nigeria. The choice of these theories is as a result of their strengths and efficacy to explicate the political phenomenon under investigation.

The goal-setting theory was propounded by Edwin Locke in 1968. According to Locke (1968), the assumption of this theory is that, it is a goal that a person is aiming for that actually motivates him and not just the satisfaction of attaining it. Therefore, the desire to attain set goals becomes a major driving force which propels people to greater achievement.

By application of this theory to the study on the implication of the 2011 general elections on democracy and good governance in Nigeria, we argue that Nigerians were poised to correct past errors in the country's electoral process starting from the 2011 general elections. Also, the electoral body (INEC), political parties, security agents, the media, civil society organizations, among others, openly informed Nigerians that they were committed to ensuring a free, fair and credible polls election during the 2011 general elections. They, therefore, demonstrated this at different public forum before the commencement of the election on April 9,2011 . In such forum, all stakeholders were urged to perform their statutory roles in order to ensure credible polls. Thus, the extent to which these stakeholders performed their assigned roles during the 2011 general elections could serve as veritable platform to evaluate the credibility of this election as well as the expected service delivery to Nigerians in the next four years.

To further investigate the activities and roles performed by major stakeholders during the process, structural - functional approach is adopted in this study. This theory assists us to examine the roles of the key stakeholders during the 2011 general elections such as the INEC, political parties, the security agents, the media, civil society organizations, among others. This theory, however, was propounded by Talcott Parsons (Eminue, 2001). According to Parsons, every political system has four basic functions to perform in the society. These functions are; adaptation, goal attainment, integration and pattern maintenance (Eminue, 2001 :89).

Thus, structural - functional approach emphasizes the role of structures and functions in understanding politics and political process. In this investigation, the structures include the INEC, political parties, security agents, the media and civil society organizations. These structures had respective roles they performed during the 2011 general elections in Nigeria.

Therefore, the credibility or abysmal failure of the 2011 general elections in Nigeria could be effectively and accurately determined when one evaluates the extent to which these structures performed their respective functions before, during and after the election. This is succinct because, this theory posits that any lacuna in role performance by a unit, ultimately affects the activities of the entire system.

Consequently, the agitations characterizing the outcome of the 2011 Presidential election in Nigeria; National Assembly election, Governorship and State Assembly elections, could be traceable to abysmal failure of some of these structures to perform their assigned functions as stipulated in the amended 1999 Constitution and 2010 Electoral Act of Nigeria. 


\section{THE INDEPENDENT NATIONAL ELECTORAL COMMISSION AND ADMINISTRATION OF THE 2011 GENERAL ELECTIONS IN NIGERIA}

Ahead of the 2011 general elections in Nigeria, the INEC was re-shuffled by President Goodluck Jonathan-led administration. This followed the expiration of the tenure of the former INEC boss, Professor Maurice Iwu. The re-organization of the INEC resulted in Professor Attahiru Jega becoming the new INEC chairman.

In line with the determination and promise of President Goodluck Jonathan that all votes would count in the 2011 general elections, the new INEC boss, Prof. Jega also made a vow to Nigerians that the 2011 general elections would be free, fair and credible. According to him, the 2011 general elections would not only be generally accepted by Nigerians, but also the international community. Thus, to elicit the supports and co-operations of various segments of Nigeria, Prof. Jega sought for collaboration of the INEC with other relevant organizations such as the NYSC, ASUU, NLC, the Media houses and the security agencies (Ologun and Oyekunle, 2010).

In preparation of the 2011 general elections, the INEC embarked on voter registration exercise. This exercise was designed to register all eligible voters in Nigeria. To achieve desired goal in this process, INEC resorted to the use of the Direct Data Capture (DDC) machine.Accordingly, the use of the DDC machine was not only meant to prevent multiple registrations, but also to ensure that only eligible voters from 18 years and above were adequately registered. Paradoxically, the 2011 voter registration like others before it was characterized by numerous setbacks and complaints. For instance, the former Governor of Borno State, Alhaji Ali Modu Sheriff was among numerous Nigerians that were pessimistic over the deadline for the voter registration exercise. According to the Governor:

...I wonder if we will be able to get all Nigerians registered before the end of the stipulated period. I believe that unless something is done urgently, many Nigerians will not be able to register... (Jimoh, 2011).

The voter registration exercise was also alleged to be marred with irregularities. Thus, there were several allegations of missing of Direct Data Capture Machines in some parts of Nigeria such as Kwara State. According to Bolaje,( an ANPP Chieftain in Kwara State):

...we heard reliably that 200 DDC machines are missing in the state. These machines are meant for places like my point and other points. These 200 we believe are somewhere known to some INEC officers in the state...(Jimoh, 2011:5).

Although INEC dismissed the above allegation by the Kwara State ANPP Chieftain, most Nigerians were startled to observe that some unscrupulous politicians in some parts of the country connived with the INEC registration officers to register under-aged voters (children below 18 years). Similarly, some Nigerians equally alleged that the voter registration exercise witnessed multiple registrations through the use of 'palm kernel shell' for thumbprinting. According to some observers of the registration process, the 'shell of palm kernel' was used for thumb-printing thereby enabling some political parties register fictitious names during the exercise. Apart from allegations of corruption leveled against the conduct of voter registration by the INEC, the exercise witnessed technical problems, particularly on the use of the Direct Data Capture (DDC) gap machines. In most rural areas where there is no electricity, the registration officers were confronted with the challenges of charging the DDC machines. 
Also, since generator sets were not provided to registration officers by the INEC, the exercise witnessed unprecedented set-backs particularly in the rural areas.

Indeed, some of the DDC machines developed unanticipated faults at various registration centers thereby preventing some eligible voters to register. To arrest this situation, INEC opted for deploying technicians to local government areas across the country. Babalola (2011) observed:

...the Independent National Electoral Commission (INEC) has concluded arrangements to deploy two technicians to each of the 774 local governments in the country... to fast-track the voter registration which began on a sluggish note... INEC has deployed two information Communication Technology (ICT) technicians per local government to troubleshoot at registration centres that might be running into hitches... (The Nation, p. 4).

Accordingly, the 2011 voter registration exercise could not satisfy the expectations of Nigerians. According to Prof. Jega, only 35 percent of Nigerians were registered in the 2011 voter registration exercise. What this implies is that many Nigerians were disfranchised even before the conduct of the 2011 general elections by the INEC.

In spite of this ugly trend, INEC informed Nigerians that the 2011 general elections would be transparent and entirely distinct from previous elections conducted. This was followed by the release of election time table by the commission. Accordingly, the National Assembly Polls was slated for January 15, 2011 and presidential polls, January 22, 2011, (Awowole - Browne, 2010).

Thus, political parties were mandated to start campaign from October 17, 2010 while voter registration was to commence on November I, and ends on November 14, 2010. Also, party primaries was slated for September 11, 2010 and ends on October 30, 2010 (Awowole Browne, 2010:7, Ejembi, 2010).

Unfortunately, the INEC could not stick to the above election time-table. The commission later amended the time table with flimsy excuses which attracted the rage of some Nigerians against the body. However, the National Assembly election slated for January 15, 2011 was rescheduled for April 2, 2011, presidential election to April 9, instead of January 22, 2011 and Governorship and State Assembly elections to April 14, 2011.

In its characteristic manner, this amended election time table was not respected by the INEC. Hence, the commission after several 'cook and bull stories', amended the election time table the third time. Hence, the National Assembly election was changed from April 2 to April 9, 2011, Presidential Election to April 14 instead of April 9, 2011, while Governorship and State Assembly Election were changed from April 14 to April 26, 2011. The reason for changing the election time-table this time particularly when Nigerians were determined to vote candidates of their choice, was largely due to late arrival of election materials.

To be sure, the National Assembly election held on April 9, 2011 was relatively free, fair and credible, although there were reported packets of violence in some parts of the country like Abia, Imo, Anambra, Borno, Benue and Akwa Ibom States. However, the conduct of the 
National Assembly election was comparatively more transparent than similar elections conducted in 1999, 2003 and 2007 in Nigeria.

Similarly, the April 16, 2011 Presidential Election was adjudged credible. Thus, in spite of the absolute control of the Congress for Progressive Change (CPC), in the North-West geo-political zone, and some other parts of the North, the People's Democratic Party (PDP) candidate - Dr. Goodluck Jonathan appeared to be the most acceptable at the polls by Nigerians. Thus, despite the fact that most Nigerians cherish his 'political credentials', Dr. Goodluck Jonathan toured the 36 states of the federation and FCT Abuja for his campaign. Also, his wife - Dame Patience Jonathan was reportedly busy touring all parts of Nigeria, begging women to vote for her husband during the presidential election. Thus, table 1.1 below shows Dr Jonathan acceptability by voters before April 16, 2011 presidential election in Nigeria:

Table 1.1: State By State Analysis Of The Acceptability Of Major Presidential Aspirants By Voters Across The Six Geo-Political Zones Prior To April 16, 2011 Presidential Election In Nigeria.

\begin{tabular}{|l|l|l|l|l|l|l|l|}
\hline S/N & $\begin{array}{l}\text { Presidential } \\
\text { Aspirant }\end{array}$ & $\begin{array}{l}\text { North- } \\
\text { Central }\end{array}$ & $\begin{array}{l}\text { North- } \\
\text { East }\end{array}$ & $\begin{array}{l}\text { North- } \\
\text { West }\end{array}$ & $\begin{array}{l}\text { South- } \\
\text { East }\end{array}$ & $\begin{array}{l}\text { South- } \\
\text { South }\end{array}$ & $\begin{array}{l}\text { South- } \\
\text { West }\end{array}$ \\
\hline 1 & $\begin{array}{l}\text { Muhammadu } \\
\text { Buhari }\end{array}$ & $5.7 \%$ & $62.3 \%$ & $38.3 \%$ & $0.2 \%$ & $0.9 \%$ & $0.2 \%$ \\
\hline 2 & $\begin{array}{l}\text { Goodluck } \\
\text { Jonathan }\end{array}$ & 28.4 & 26.6 & 47.4 & 75.1 & 82.7 & 50.8 \\
\hline 3 & Nuhu Ribadu & 5.7 & 2.1 & 4.5 & 0.9 & 1.6 & 15.6 \\
\hline 4 & $\begin{array}{l}\text { Ibrahim } \\
\text { Shekarau }\end{array}$ & 1.7 & 2.9 & 0.8 & 2.4 & 0.4 & 0.2 \\
\hline 5 & Others & 15.0 & 5.9 & 0.2 & 1.3 & 0.2 & 1.6 \\
\hline 6 & No Response & 41.7 & 5.9 & 8.7 & 20.1 & 13.2 & 31.6 \\
\hline
\end{tabular}

Source: Okoro, C. P. (2011).

From table 1:1 above, we observed that Goodluck Jonathan and Muhammadu Buhari were the two major contestants in the 2011 general election in Nigeria. Accordingly, the above table shows that Goodluck Jonathan was not only accepted in the South-South geo-political zone, where he come from, but also accepted in the other five geo-political zones of the country. This was followed by Buhari, Ribadu, Shekarau and other contestants.

However, the April 26, 2011 governorship and State Assembly elections in Nigeria witnessed tremendous rigging than the situation in 1999, 2003 and 2007 elections. In 1999, 2003 and 2007 governorship elections in Nigeria, the electorates were allowed to vote at their respective polling centres. Thus, it was after voting that political parties connived with the INEC officials and security agents to manipulate and doctor the results. In 1999, 2003 and 2007 governorship elections, the remaining ballot papers after the registered and eligible voters had casted their votes were shared by party agents representing the major political parties to thumb print in favour of their respective parties (Akiri, 2010).

Contrary to this subtle method of rigging by political parties in Nigeria, the April 26, 2011 governorship elections witnessed another radical, fraudulent and aggressive strategy of election rigging. Thus, the electorates were not only disfranchised but voting took place at the personal residence of some party stalwarts notably those belonging to PDP. Consequently, this unlawful electoral practice resulted in violence in some states in Nigeria as presented in table 2.2 below: 
Table 2.2: States With Reported Cases Of Electoral Violence Occasioned By Rigging/Malpractice During The 2011 Governorship And State Assembly Polls In Nigeria.

\begin{tabular}{|c|c|c|}
\hline S/N & STATES & PARTY SUPPORTERS INVOLVED \\
\hline 1 & Benue & PDP vs CPC \\
\hline 2 & Akwalbom & PDPvsACN \\
\hline 3 & Bauchi & PDP vs CPC \\
\hline 4 & Yobe & PDP vs APGA \\
\hline 5 & Abia & ANPP vs PDP \\
\hline 6 & Borno & ANPP vs PDP \\
\hline 7 & Kano & ANPv PDP \\
\hline 8 & Oyo PDP \\
\hline 9 & Kebbi & ACN vsPDP \\
\hline 10 & Ogun & PDP vsCPC \\
\hline 11 & Jigawa & CPC vs PDP \\
\hline 12 & Nasarawa & PDP vs CPC \\
\hline 13 & Kaduna & \\
\hline
\end{tabular}

Source: ThisDay Newspaper, May 17 2011,p.17

From table 2:2 above, it is observed that electorate violence mostly occurred in the northern part of Nigeria than the southern part of the country. Clearly, out thirteen states computed in the above table, nine states are located in the northern part of Nigeria, while five are located in the southern part of the country. It is not arguable that the reason for such violence was purely to rig the election

Thus, to achieve the objectives of this new methodology of election rigging by political parties in Nigeria, the PDP allegedly made tactical and financial arrangements for security agents. The party even lured the police, Army, Navy and Civil Defence corps deployed by the INEC to various states, to enable her perfect this unlawful strategy. These security agents were allegedly paid colossal sum of money by the PDP at the ward, local and state levels to assist her rig the election. According to critics, this strategy explains why the budget for the conduct of governorship elections by the party at the ward, local and state levels gulfed huge sum of money than other logistics during the April 26, 2011 governorship and State Assembly elections (The Nation, May 22, $2011: 3$ ).

Generally speaking, the conduct of the 2011 general elections by the INEC though better than the 1999, 2003 and 2007 general elections, appeared not entirely free, fair and credible as the commission promised Nigerians. This view is supported by Somorin (2011:15). According to him, "a chieftain of the PDP in Abia State, Sir Marc Wabara has called on President Goodluck Jonathan to start the healing process of the country".

In his opinion, somorin noted that Wabara called on:

...President Goodluck Jonathan to start the healing process of the country as a result of the violence that erupted in some parts of the country after the presidential election... the president should begin the process of healing all the wounds that may have been created by "our" actions and inactions as a people...

In spite of the position of some Nigerians concerning the credibility to the 2011 general elections, the European Union Election Observation Mission to Nigeria asserted that there 
were no reports of rigging during the 2011 general elections. Thus, Adesina (2011) shades more lights on the position of the EU election observers:

...the European Union Election Observation Mission to Nigeria reacted to the allegation by the presidential candidate of the Congress for Progressive Change (CPC), Major General Muhammadu Buhari, that the last presidential election in the country was rigged and that "sophisticated rigging system was deployed to perpetrate electoral malpractices during the polls... Mr. Peterle while presenting a preliminary report, stated that there was considerable improvement in Nigeria's quest for democracy...the overall desire of Nigerians in 2015 should be to achieve zero violence before, during and after elections... (EM News online, April 19, 2011).

Thus, notwithstanding the argument on the conduct and credibility the 2011 general elections, the critical fact is that stakeholders in the said election should be blamed for its poor outcomes in some States. This is largely because, as Akiri (2010:21) incisively observed:

...Whereas the success or failure of any election anywhere in the world, depends on all the stakeholders comprising the electorates, security agencies, but more particularly on the electoral umpire which in the case of Nigeria is INEC... the success or failure of any electoral process, anywhere in the world, is contingent upon the integrity of the electorates, the security agencies, the judiciary, the press... (National Daily Newspaper, p. 8).

Consequently, the increasing spate of agitations, hostilities and post-election violence in some parts of the country such as Benue, Akwa Ibom, Abia, Imo, Bauchi, Borno, Kaduna, Abuja, among others, are no doubt, clear indication that some stakeholders in the 2011 general elections compromised in the discharger of their civic responsibilities.

\section{THE ROLES OF POLITICAL PARTIES, SECURITY AGENCIES AND THE MEDIA DURING THE 2011 GENERAL ELECTIONS IN NIGERIA}

Political party is a formal organization whose primary objective is to nominate candidates for election to public offices, with the ultimate intention of gaining absolute control of personnel, policies and decision-making processes of government (Nwosu and Ofuegbu, 1986:187). In order to realize the above lofty goal, political parties pursue programmes of action ultimately aimed at achieving politically significant values (Ekwueme and Fidelis, 1990:68). Thus, the measure of a party's success in realizing the dream of controlling the decision-making apparatus of the state is in the main, a product of its organization's capability and popular appeal of its policies and programmes to the electorates (Duru and Nwagboso, 2005: 112).

However political parties, irrespective of their types, have certain features in common. First, they are hierarchically organized; second, they are programmatic (i.e. they always have action plans for promoting the general welfare and ushering in good life for all), and third, they recruit personnel for the government (Eminue, 2001:329). Thus, political parties anywhere in the world perform multifarious functions in democratic political systems. This include; political recruitment function, political education, integrative function; aggregative function; mobilization function; goal formation function; enforcement of responsibility function, among others (Ikpe, 2010: 409).

Consequently, few months to the 2011 general elections in Nigeria, political parties were engulfed in several crises. Rather than strategizing to capture state's power, political parties 
particularly the major ones, such as the People's Democratic Party (PDP), Congress for Progressive Change (CPC), Action Congress of Nigeria (ACN), All NigeriaPeople's Party (ANPP), Progressive People's Alliance (PPA), were faced with severe internal problems in their parties (Alli, 2010: 1). This problem ranges from the struggle among the party stalwarts to control the leadership or structures of their parties, politically-motivated assassination of party members with intentions for elective positions, court injunctions/litigations, to allegations of corrupt charges against some party helmsmen.

This ugly trend which heated up the Nigeria's political environment, no doubt put these political parties in disarray ahead of the April 2011 general elections. Thus, the political parties dissipated more energy fighting among their members rather than marshalling out action plans to win the supports of the electorates in Nigeria (Alli, 2011:1).

Specifically, the removal of the former PDP National Chairman, Chief Vincent Ogbulafor from office on allegation of corruption, and Dr. Okwesilieze Nwodo on the grounds that it was not up to two years he returned to the PDP before assuming the office of the National Chairman of the party, were clear testimonies of "in-house" crises that rocked most political parties in Nigeria shortly before the 2011 general elections (Fabiyi, 2010: 10). The same ugly scenario resulted in the resignation of Chief Clement Ebiri as the National Chairman of the PPA in Nigeria.

Consequently, these pathetic situations resulted in some members of the above political parties defecting to other political parties particularly the newly formed parties.

However, the internal crises in some political parties ahead of the April 2011 general elections in Nigeria further manifested during party primaries. Thus, the disagreement among some party helmsmen resulted in the imposition of candidates on party members. Precisely, the democratic ethos requires that political parties must conduct primaries in a manner generally acceptable by their members (Okocha, 2010:15).

Unfortunately, this rule was not strictly followed in the emergence of party flag-bearers in most political parties that contested the 2011 general elections in Nigeria. Worse still, this situation coerced aggrieved members of the affected parties to seek redress in the court. This step by the aggrieved members exacerbated internal cohesion and solidity in the affected parties such as the PDP, PPA, ANPP, CPC among others. Indeed, the failure to conduct credible primaries by political parties before the commencement of the 2011 general elections did not only affect adversely the growth of internal democracy, but also raises critical questions on the credibility, free and fair outcome of the 2011 general elections.

However, the internal crises that 'rocked' major political parties in Nigeria and their implications on democracy are carefully articulated by Akinola (2011):

Political parties are best described as 'rivals' for power rather than being apposing parties in the context of adversarial politics... the role of the political party as an agent of integration, rather than that of sharing loots, would be more appreciated when we have had competitive political parties that traverse regional divides...(The Punch, $p$. 16).

The consequence of this ugly scenario during the April 2011 general elections resulted to the adoption of different strategies by political parties to rig the election. To some observers, all 
the political parties that participated in the 2011 general elections involved election in rigging and other forms of malpractices. This assertion is corroborated in table .33 below:

Table 3.3: $\quad$ A Sample Of States And Geo-Political Zones With Reported Cases Of Rigging During The April 26, 2011 Governorship And Stateassembly Elections In Nigeria.

\begin{tabular}{|l|l|l|c|}
\hline S/N & \multicolumn{1}{|c|}{ STATE } & \multicolumn{1}{|c|}{ GEO-POLITICAL ZONE } & POLITICAL PARTY INVOLVED \\
\hline 1 & Abia & South- East & PDP \\
\hline 2 & Akwa Ibom & South-south & PDP \\
\hline 3 & Kwara & North -Central & PDP \\
\hline 4 & Borno & North -East & PDP \\
\hline 5 & Jigawa & North - West & ACN \\
\hline 6 & Oyo & South - West & . \\
\hline
\end{tabular}

Source: www.electionsituationroom.worldpress.com./category/election- malpractices

From table 3.3 above, it is observed that election rigging during the 2011 governorship election mostly occurred in Abia, Akwa Ibom, Kwara, Borno, Jigawa and Oyo States. Also, this ugly political activity was mostly reported against the PDP, followed by ANPP and CAN respectively.

It is, imperative to note that every contest, where election is genuinely or fraudulently conducted, winners and losers must emerge. Thus, the political parties challenging the outcome of the 2011 general elections at federal and state levels in Nigeria, are clearly those who failed in their strategies and bids to rig election. This is succinct because, "no political party in the annals of the electoral history of Nigeria has ever challenged its victory secured by rigging and fraud in court".

On the other hand, security agencies are indispensable apparatus to ensure violent-free polls in all democratic states in the world. In Nigeria, several security agents participated in the 2011 general elections. The roles of these security agents in the 2011 general elections have continued to attract mix reactions among the electorates in Nigeria. This is partly because, a cursory survey of the activities of some members of the Nigerian Police, State Security Services (SSS), the Army, the Navy, Civil Defence Corps, among others, reveals a high level of complacency (Ogunmadu, 2011:16).

In Abia State for instance, the PDP connived with some of these security agents to intimidate political opponents and electorates during the Governorship and State Assembly Polls. Thus, these security agents were paid colossal sum of money for this undemocratic engagement. As a result of this, most electorates remained in their homes rather than coming out to exercise their constitutional rights. Worse still, election in places like Ehi-Na-Uguru/Osokwa Ward 5, was conducted at the personal residence of Chief Chinagorom Nwankpa - the former Executive Chairman of IsialaNgwa South Local Government Area of Abia State. Thus, the security agents - the Police, Army, Navy and Civil Defence Corps were all over Chief Nwankpa's residence, ensuring that the election that was bid by the INEC to take place at the twenty polling centres in the said political ward was effectively conducted in Chief Nwankpa's house. The same situation was reported to have occurred in some states in Nigeria like Benue, Jigawa, Kwara, Akwa Ibom, Bauchi, Borno and Yobe (Aladelokun, 2011:3).

Similarly, there were reported cases of fraudulent election malpractices in Imo State. According to Okwuofu and Oladele (2011:1), the CPC alleged that the PDP, INEC and security agents connived to rig the April 16 presidential elections at Ohaji/Egbema and Oguta Local 
Government Areas. The same thing was applicable to Owerri Municipal Council and Orlu Local Government Areas of Imo State. In these places, the CPC also alleged that amidst tight security, the INEC officials were seen thumb-printing ballot papers in favour of the PDP candidates during the April 9 and 16, 2011 General Elections.

Contrarily, the role of the media in the April 2011 general elections in Nigeria has been commended by most Nigerians and international observers. Thus, the Federal Radio Corporation of Nigeria (FRCN), the Nigerian Television Authority (NTA), the African Independent Television (AIT), the Channel Television, the Print Media, among others, discharged their statutory roles during the April 2011 elections with fair degree of objectivity.

Thus, the media is charged with the responsibility of informing, educating and entertaining the members of the public on plethora of events that take place in the society. However, this responsibility spans all facets of activities and human endeavours in the global. Therefore, the coverage of elections and consequent reportage of the events to the public are integral part of the critical roles of the media in democratic political environment. Thus, the NTA, FRCN, AIT, the Channels Television and Newspaper houses, kept Nigerians and the international community abreast of the events that took place during the 2011 general elections. Before the commencement of the 2011 general elections, the NTA, FRCN and print media promised to give equal opportunities to all political parties wishing to show-case their manifestoes to the electorates. They further promised for effective coverage of their campaigns, rallies, press conferences, among others. The media fulfilled this promise as evidenced in table 4.4 below:

Table 4.4: Total Time Allocated To The Political Actors (Without Paid Advertisement) By The Media, During The 2011 General Elections In Nigeria.

\begin{tabular}{|l|l|l|l|l|l|l|l|l|}
\hline S/N & PARTIES & ASO FM & $\begin{array}{l}\text { KAPITAL } \\
\text { FM }\end{array}$ & $\begin{array}{l}\text { RAY } \\
\text { POWER }\end{array}$ & $\begin{array}{l}\text { FRCN } \\
\text { KADUNA }\end{array}$ & $\begin{array}{l}\text { RADIO } \\
\text { UNITY }\end{array}$ & $\begin{array}{l}\text { RADIO } \\
\text { KANO }\end{array}$ & $\begin{array}{l}\text { FREEDOM } \\
\text { RADIO }\end{array}$ \\
\hline 1 & PDP & $79.71 \%$ & $64.05 \%$ & $61.94 \%$ & $53.52 \%$ & $61.66 \%$ & $34.34 \%$ & $33.20 \%$ \\
\hline 2 & ANPP & $3.44 \%$ & $1.27 \%$ & $6.84 \%$ & $17.97 \%$ & $1.53 \%$ & $56.02 \%$ & $21.46 \%$ \\
\hline 3 & CPC & $5.34 \%$ & $4.81 \%$ & $7.21 \%$ & $13.05 \%$ & $7.08 \%$ & $4.98 \%$ & $35.21 \%$ \\
\hline 4 & ACN & $8.17 \%$ & $4.98 \%$ & $14.07 \%$ & $6.86 \%$ & $7.10 \%$ & $3.79 \%$ & $9.10 \%$ \\
\hline 5 & NTP & $0.27 \%$ & $7.41 \%$ & $0.37 \%$ & $0.00 \%$ & $7.15 \%$ & $0.00 \%$ & $0.07 \%$ \\
\hline 6 & UNPD & $0.09 \%$ & $7.02 \%$ & $0.00 \%$ & $0.00 \%$ & $7.05 \%$ & $0.00 \%$ & $0.00 \%$ \\
\hline 7 & SDMP & $0.38 \%$ & $5.36 \%$ & $0.88 \%$ & $0.53 \%$ & $5.21 \%$ & $0.48 \%$ & $0.11 \%$ \\
\hline 8 & LP & $1.55 \%$ & $2.56 \%$ & $1.24 \%$ & $2.20 \%$ & $0.84 \%$ & $0.27 \%$ & $0.15 \%$ \\
\hline 9 & APGA & $0.29 \%$ & $1.31 \%$ & $1.34 \%$ & $0.00 \%$ & $1.69 \%$ & $0.00 \%$ & $0.28 \%$ \\
\hline 10 & Others & $0.28 \%$ & $1.28 \%$ & $6.12 \%$ & $5.88 \%$ & $0.69 \%$ & $0.12 \%$ & $0.42 \%$ \\
\hline Base: & & $\begin{array}{l}9 \mathrm{~h} \\
20 \mathrm{~min}\end{array}$ & $\begin{array}{l}10 \mathrm{~h} \\
57 \mathrm{~min}\end{array}$ & $\begin{array}{l}10 \mathrm{~h} \\
45 \mathrm{~min}\end{array}$ & $4 \mathrm{~h} 58 \mathrm{~min}$ & $\begin{array}{l}11 \mathrm{~h} \\
\mathrm{~min}\end{array}$ & $\begin{array}{l}10 \mathrm{~h} \\
56 \mathrm{~min}\end{array}$ & $14 \mathrm{~h}, 49 \mathrm{~min}$ \\
& & & & & & \\
\hline
\end{tabular}

Source: Adesina, J.N. (2011).

From table 4.4 above, we observed that the media made frantic effort to keep Nigerians abreast of the activities characterizing the 2011 general elections. This commitment resulted to the efforts of the media to advertise political activities of major political parties during the election. Unfortunately, many observers have argued that the free media advertisement granted to political parties favoured the PDP than other political parties as evidenced in the computed percentages above.

Similarly, the total time allocated to presidential aspirants by the media during the 2011 general elections is shown in table 5.5 below: 
Table 5.5: A Sample Of Total Time Allocated To Presidential Aspirants In The News During The 2011 General Elections In Nigeria.

\begin{tabular}{|l|l|l|l|l|}
\hline S/N & CANDIDATES & AIT & CHANNELS TV & NTA \\
\hline 1 & Goodkuck Jonathan & $82.69 \%$ & $34.90 \%$ & $81.87 \%$ \\
\hline 2 & RibaduNuhu & $3.03 \%$ & $18.58 \%$ & $4.75 \%$ \\
\hline 3 & Shekarau Ibrahim & $1.23 \%$ & $19.77 \%$ & $3.57 \%$ \\
\hline 4 & BuhariMuhammadu & $9.21 \%$ & $7.73 \%$ & $5.18 \%$ \\
\hline 5 & Momodu Dele & $0.14 \%$ & $16.18 \%$ & $0.57 \%$ \\
\hline 6 & Chris. Okotie & $8.74 \%$ & $8.43 \%$ & $1.85 \%$ \\
\hline 7 & Others & $3.71 \%$ & $2.85 \%$ & $0.2 \%$ \\
\hline & Base: & $5 \mathrm{~h} 2 \mathrm{~min}$ & $13 \mathrm{~h} 48 \mathrm{~min}$ & $15 \mathrm{~h} 49 \mathrm{~min}$ \\
\hline
\end{tabular}

Source: Adesina, J.N. (2011).

From table 5.5 above, it is observed that media coverage was also extended to presidential aspirants during the 2011 presidential election. The major media houses were the AIT, Channel TV and NTA. From the statistics above, the activities of the candidate of PDP was mostly covered than those of other political parties.

Notwithstanding, the NTA and FRCN performed excellently in the area of broadcasting and announcement of election results by Returning Officers across Nigeria. Thus, Nigerians were availed the opportunity of watching the live coverage of the announcement of election results, while those with radios listened to the events on air.

In spite of these galant efforts by the media during the April 2011 general elections, some Nigerians have criticized its activities. To some Nigerians, there was no wide coverage of the events that took place during the 2011 general elections in Nigeria (Egbu, 2011:67). To them, however,only events that took place in the urban centres were reported to Nigerians.

\section{THE 2011 GENERAL ELECTIONS, DEMOCRACY AND GOOD GOVERNANCE IN NIGERIA}

There is a correlation between credible election and achievementment of good governance in liberal democratic political environment. This is largely because, free, fair and credible elections have the propensity of ushering in policies and programmes capable of promoting the general well-being of the citizens in the state (Babab' Umma, 2009:89). Thus, free, fair and credible election ultimately enhances security and efficient service delivery to the people such as water, education, health, employment, road, wealth creation, among others. It also promotes the adherence and application of the rule of law by the government in power. Consequently a critical look at table 6:6 below helps in painting the picture of the expectations of the electorates from those they elected during elections such as the April 16, 2011 Presidential elections in Nigeria:

Table 6.6 shows that the PDP candidate (Goodluck Jonathan), scored the highest number of valid votes during the 2011 presidential election in Nigeria. This was followed by the candidates of CPC, CAN, PDC, PMP, among others.

The above performance notwithstanding, it is pertinent to note that any, election characterized by imposition of candidates on the party members/electorates, intimidation of opponents and electorates with thugs/fiercely looking security agents, rigging, agitations and other fraudulent practices, adversely effect not only the growth of democracy but also the efficacy of service delivery to the citizens by elected political office-holders. 
Table 6.6: Summary Of April 16, 2011 Presidential Election Result In Nigeria

\begin{tabular}{|l|l|l|l|l|}
\hline S/N & CANDIDATES & PARTIES & VOTES & \% \\
\hline 1 & Goodluck Jonathan & People's Democratic Party (PDP) & $22,495,187$ & 58.89 \\
\hline 2 & MuhammaduBuhari & Congress for Progressive Change (CPC) & $12,214,853$ & 31.98 \\
\hline 3 & NuhuRibadu & Action Congress of Nigeria (ACN) & $2,079,151$ & 5.41 \\
\hline 4 & Ibrahim Shekarau & All Nigeria people's Party (ANPP) & 917,012 & 2.40 \\
\hline 5 & MahamudWaziri & People for Democratic Change (PDC) & 82,243 & 0.21 \\
\hline 6 & NwadikeChikezie & Peoples Mandate Party (PMP) & 56,248 & 0.15 \\
\hline 7 & Lawson IgboanugoAroh & Peoples Progressive Party (PPP) & 54,203 & 0.14 \\
\hline 8 & Peter Nwangwu & African Democratic Congress (ADC) & 51,682 & 0.14 \\
\hline 9 & IheanyichukwuNnaji & BetterNigeria Progressive Party (BNPP) & 47,272 & 0.12 \\
\hline 10 & Chris. Okotie & Fresh Democratic Party (FRESH) & 34,331 & 0.09 \\
\hline 11 & Dele Momodu & National Conscience Party (NCP) & 26,376 & 0.07 \\
\hline 12 & Akpona Solomon & National Majority Democratic Party (NMDP) & 25,938 & 0.07 \\
\hline 13 & LawrenceMakindeAdedoyi & African Political System (APS) & 23,740 & 0.06 \\
\hline 14 & EbitiNdok & United National Party for Development & 21,203 & 0.06 \\
& & (UNPD) & & \\
\hline 15 & John Dara & National Transformation Party (NTP) & 19,744 & 0.05 \\
\hline 16 & Rasheed, Shitta-Bey & Mega Progressive Peoples Party (MPPP) & 16,492 & 0.04 \\
\hline 17 & YahayaNdu & African Renaissance Party (ARP) & 12,264 & 0.03 \\
\hline 18 & Ambrose Awuru & Hope Democratic Party (HDP) & 12,023 & 0.03 \\
\hline 19 & PatUtomi & Social Democratic Mega Party (SDMP) & 11,544 & 0.03 \\
\hline 20 & Chris. Nwaokobia & Liberal Democratic Party of Nigeria (LDPN) & 8,472 & 0.02 \\
\hline & Invalid votes & & $1,259,506$ & 3.19 \\
\hline & Valid votes & & $39,469,484$ & 96.81 \\
& $53.7 \%)$ & & & \\
\hline
\end{tabular}

Source: www.inec.ng.org.

This is succinct because, available evidence has shown that irregularities such as imposition of candidates and consequent litigation by aggrieved party members characterized party primaries by most political parties that participated in the 2011 general elections in Nigeria (Edike, 2010:13; Dayo, 2010:1; Otabor, 2011:8, Nation, April 2011, p. 1).

Thus, since there was no harmony and internal cohesion among some party members such as the PDP, CPC, ANPP and PPA, these parties could not 'speak with one voice'. However, these political parties that were already weakened by internal wrangling and crises obviously found it difficult to strategize and even carry out serious campaigns to all nooks and crannies of the Nigerian state to win the supports of the people (Idris, 2011:20).

However, as candidates of political parties that were successful in rigging the 2011 governorship and States Assembly elections have assumed offices, Nigerians are most likely to be denied better service delivery in the affect states. This is partly because, in liberal democratic states, the citizens are constitutionally given "free hands" to choose those to represent them. The citizens are, therefore, obliged to elect only those capable of providing efficient and people-oriented services to them (Dinneya, 2006:52). Thus, the import of efficient service delivery to the citizens by elected public officials particularly in Nigeria is properly articulated by Olowu (2002: 123) that:

...the ability of a government to legitimately tax and govern people is premised on its capacity to deliver a range of services required by its population which no other player will provide... 
However, we argue from the above premise that why development has remained elusive in Nigeria is that the citizens are always denied their constitutional rights of electing those to govern them. The political office-holders who assumed their positions by fraud, do not own allegiance to the people (Duru, 2002:46). Hence, such public functionaries abysmally fail in the area of providing to the people, portable water, health, services, access road, electricity, security, employment, education, among others. Consequently, failure of the leaders to provide these essential and indispensable services to the people do not only result to severe poverty in the state, but also triggers off youth restiveness, poor health status, cyber crimes, prostitution, armed robbery, kidnapping and other forms of social vices, particularly among the youths in Nigeria.

It is imperative to note that the principle of accountability expected to be adhered to by public office-holders is usually compromised, if the occupants were not duely elected to public offices by the people. This is because, public accountability is not only an indispensable feature of democracy but also a critical platform through which the people view the actions and inactions of their elected leaders. Also, the adherence of the elected officials to the tenets of public accountability, offers both the government and the people the opportunity of identifying critical developmental challenges confronting the state as well as appropriate people-oriented strategies to address them.

In Nigeria, the widely reported cases of corruption and abuse of public offices could be traceable to the conduct of fraudulent elections, lack of participation in decision making by the people, lack of public accountability by public office-holders, among others (Dinneya, 2006:24). As Late President Yar'Adua once noted "a corrupt person" cannot provide credible leadership (Shaibu, 2008:6). Hence, these unethical practices, no doubt, will certainly result to poor conduct of governmental affairs in Nigeria from 2011 to 2015, particularly in some states where elections were rigged. This is succinct because, the results of the 2011 general elections particularly the Governorship and State Assembly elections witnessed the emergence of candidates who were out-rightly rejected before the election by both their party members and large number of eligible voters in their constituencies.

Thus, as these 'political hawks' have assumed power across the country, the fact that the people would be eliminated in policy making process of the government in the affected areas cannot be underestimated (Ogbodo and Njoku, 2009:1). Therefore, the ugly and criminal activities of some stakeholders in the 2011 general elections such as the INEC officials/adhoc staff, the political parties and security agencies, would not only affect adversely the participation of the people in governance process, but also results in apathy among them during the 2015 general elections in Nigeria.

This ugly trend which would be attributed at the long run as bad leadership captured the views of Yusuf (2011: 18).

Over the years, corruption has weakened the three levels of government in Nigeria and their ability to promote development and social justice... corruption undermines development by distorting the rules of law and weakening the institutional foundation on which economic growth depends... what should be paramount in the minds of many... is whether things are getting worse off or better at the moment... there is the need for paradigm shift towards addressing the critical challenges of governance rather than engaging in wanton profligacy... 
Thus, unless stringent steps are taken by anti-graft agencies - the EFCC and ICPC, to checkmate the activities of some public official that rigged themselves in office during the 2011 general elections in Nigeria and further remind them of facing prosecution on the grounds of enriching themselves while in office, the delivery of dividend of democracy to Nigerians in the next four years (2011-2015), would be elusive.

\section{CONCLUSION}

The challenges of administering credible elections have continued to cascade the growth of democracy and achievement of good governance in Nigeria. The 1979, 1993, 1999, 2003, 2007, and 2011 general elections in Nigeria were replete with agitations, consternations and general disenchantment among political parties. Thus, the 2011 general elections though comparatively better than previous elections in Nigeria, was not completely devoid of rigging, fraud and post election violence (The Nation, 2011:22).

Consequently, the influx of election petitions at tribunals sitting across the federation is a pointer to the fact that the 2011 general elections in Nigeria were flawed in some states. Indeed, the most perturbing phenomenon was the deliberate disenfranchisement of eligible and registered voters in some states during the said elections, largely due to the penchant to rig the election by the stakeholders - the INEC, political parties and security agents, The political parties that were favoured by this fraudulent electoral process have continued to justify their victory and further adopted various undemocratic approach to clamp-down any possible opposition in some states of the federation.

The implication of the ugly behaviours of the stakeholders in the 2011 general elections in Nigeria is that the growth of democracy is jeopardized. Also, these 'helicopter candidates'nominated and rigged into elective positions by political parties may not visit their constituencies, let alone addressing challenges confronting their people in the next four years. This is largely because; such candidates were not elected by those they claim to be representing.

Therefore, the mistakes made by some stakeholder during the 2011 general elections will ultimately have harsh and far-reaching implications not only on democratic consolidation but also on good governance in some states in Nigeria. It will hinder efficient service delivery to the citizens and also result in apathy among the people during the 2015 general elections in Nigeria. The spill-over effects of these anomalies would be high spate of poverty among Nigerians, increase in the rate of unemployment, security problems, youth restiveness, agitation by different interest groups, and total breakdown of law and order in Nigeria.

\section{RECOMMENDATIONS}

In view of the plethora of adverse implications of the 2011 general elections on democracy and good governance in Nigeria, the following recommendations are proffered to avert impending danger in Nigeria ahead of the 2015 general elections:

1. There is the need for credible voter registration exercise before the conduct of the 2015 general elections in Nigeria. This will reduce drastically the unwanted and ugly practices of registering underage voters by politician as was the case in 2011 voter registration.

2. The INEC should implement its policy on the use of Electronic Voting System (EVS) to check election frauds by political parties during the 2015 general elections in Nigeria. 
This could be achieved through commitment and concerted efforts of government in poverty eradication and development of rural areas in Nigeria.

3. The INEC should be more proactive in implementing its earlier plan to check election violence through the use of Electoral Violence Tracking Website (EVTW). This will not only assist in curbing the menace of election violence but also help to check the activities of unscrupulous politicians in many parts of Nigeria.

4. The involvement of foreign election observers such as the European Union Election Observation Mission during elections should be avoided not only in the 2015 general elections but also in all future general elections in Nigeria. This will assist Nigerians to judge their actions and inactions during elections rather than relying on foreign observers that falsely declared that there were no reports of rigging in the 2011 general elections in Nigeria.

5. There is the need to return Nigeria to a two party state. This will not only enable the political class to fall into two ideological camps but also reduce the disaster and crises of ideological orientation among politician in Nigeria. It will further reduce confusion among electorates who frequently find it difficult to try an alternative political party whenever they are disappointed by the party in power.

6. The civil society organizations in Nigeria such as the NLC, TUC, ASUU, NBA, NMA, etc., should mount pressure on the members of the National Assembly to reverse to the status quo which stipulated that political parties mustconduct credible party primaries before elections. This will enable that section of the Electoral Act they amended for their selfish and parochial interests to be restored in order to assist Nigeria administer credible elections in 2015, starting with the conduct of credible party primaries.

7. The INEC should work assiduously to ensure that Nigerians in the diaspora vote in the 2015 general elections. This will not only enable these Nigerians make their inputs in the governance of their country, but also offer them the opportunity of influencing or changing the voting behaviours of Nigerians at home, who believe tenaciously that money politics, godfatherism, prebendalism, kleptocracy, clentelism, among others are the bane of Nigerian politics.

8. The INEC should as a matter of urgency, map out strategies to ensure adequate security in the South-East and South-South geo-political zones of Nigeria during the 2015 general elections.This will enablethe people of these zones to freely elect those to represent them at various levels in 2015.

9. The election tribunals handling cases arising from the 2011 general elections should reverse any election that was not conducted in accordance with the2010 amended Electoral Act, so as to restore sanity in Nigeria's electoral process.

10. The anti-graft agencies such as the EFCC and ICPC should beam their searchlights on the activities of members of the election tribunal handling cases arising from the 2011 general electionsespecially in the south-East and south-south geo-political zonesto ensure that they do not compromise their duties as were alleged in 2007. 


\section{References}

Akinlota, A. (May 24, 2011). Appraising party systems in Nigeria.The Punch, p.16.

Akiri, C. (June 9, 2010). INEC and the fight against electoral malpractices: Pragmatism in the arrest and prosecution of all electoral offenders. National Daily Newspaper, p.8.

Aladelokun, D. (April 28, 2011). How the parties fared. The Nation, p. 3.

Alao, O. (May 8, 2011). Malpractices were prevalent in South-East, South-South----observers. Sunday Trust, p. 6.

Alli, Y. (August 10, 2010). 2011: PDP in fresh crisis. The Nation, p. I.------(January 20, 2011). Obasanjo, governors in battle over PDP chair: Maduekwe, Anyim, two others in race to succeed Nwodo. The Nation, p. 1

Awowole - Browne, F. (September 8, 2011). 2011: Elections start Jan. 15, as INEC rolls out time table. Daily Sun, p. 7.

Babalola, J. (January 20, 2011). INEC to deploy technicians to local governments.The Nation.P. 4.

Baban’ Umma, M. B. (2009).“Democratic governance and social service delivery in Nigeria: An analysis of water and policy".Nigerian Journal of Politics and Public Policy, 5 (1 \& 2), 89 - 98.

Adesina, J.N (April 19, 2011) .No report of rigging during the April 16 presidential election in Nigeria----EU Election Observation Mission toNigeria . EM News online.

Dayo, B. (September 16, 2010). Saraki polarizes PDP Govs, leadership. Vanguard, p. 1.

Dinneya, G. (2006). Political economy of democratization in Nigeria.Lagos: Concept Publications.

Duru, E. J. C. \&Nwagboso, C. I. (2005).“The futility of the minority equation in Nigeria's electoral calculation".Calabar Journal of Polities and Administration(pp. 102 - 119.)

Duru, E. J. C. (2002). The electoral process and democracy in Nigeria.Calabar: BAAJ International Company. Edike, T. (September 16, 2010). Nnamani's faction calls for dissolution of Enugu PDP Exco. Vanguard, p. 13. Egbu, R. (June 5, 2011). The media, democracy and 2011 elections. The Sunday Sun, p. 67.

Ejembi, R. (October 7, 2010). INEC commissioner charges Nigerians on credible elections. Daily Sun, p. 12. Ekwueme, F. O. \& Fidelis, C. O. (1990).Foundation of government and politics.Ibadan: Africana - FEP Publishers. Eminue, O. (2001). Introduction to political science.Calabar: CATS Publishers.

Fabiyi, O. (May 14, 2010). At last Ogbulator resigns as PDP Chairman. The Punch, p. 10.

Idris, I. (January 20, 2011). I didn't manipulate primaries - Edo State Deputy Governor. The Nation, p.8.

Ikpe, U. B. (2010). State-society interactions: A conceptual and comparative introduction to political sociology. Lagos: Concept Publications.

Jimoh, A. (January 20, 2011). INEC, Kwara ANPP disagree over missing DDC machines. The Nation, p. 5.

Nwosu, H. N. \&Ofuegbu, R. (1986).Introduction to politics.Enugu: Fourth Dimension Publishers.

Ogbodo, J. \&Njoku, L. (July 2, 2009). Iwu laments elites resistance to free polls. The Guardian, p. 1.

Ogunmadu, O. (May 21, 2011). Rigging: EX-NBA boss,AkeredoluOsinbajo wants police, SSS prosecuted. Thisday Newspaper, p. 1.

Okocha, C. (October 13, 2010). Consensus candidate: Govs boycott c'ttee's meetings. Thisday Newspaper, p. 6. Okoro, C.P.(2011). Universal/international current affairs.Onitsha: Nobel Communications Project.

Okwuofu, O. \&Oladele, 13. (April 28, 2011). PDP takes Rivers, Abia, Enugu, Akwalbom. The Nation, p. 1.

Ologun, S. \&Oyekunle, S. (July 30, 2010). 2011:Jega seeks partnership with police. The Nation, p. 3.

Olowu, E. (2002). Public service delivery. In Adamolekun, L. (ed). Public administration in Africa: Main issues and selected country studies (pp. 123 - 138). Ibadan: Spectrum Books.

Osauzo, T. (October 7, 2010). Rigging: Oshiomhole calls for civil disobedience. The Sun, p. 13.

PM News editorial (April 26, 2011). Some crises, but governorship election in Oyo State peaceful. www.pmnewsnigeria.com Retrieved: June 9, 2011. 
Nwagbosos, C. L., \& Duke, O. (2015). The Implication of the 2011 General Elections on Democracy and Good Governance in Nigeria. Advances in Social Sciences Research Journal, 2(7) 221-238.

Report of the Civil Society Election Situation Room on April 26, elections.

www.electionsituationroom.worldpress.com/category/election-malpractices.Retrieved: June 9, 2011.

Shaibu, I. (October 16, 2008). Case against ex-govs not closed ---EFCC. Vanguard, p. 6.

Somorin, Z. (May 17, 2011). Post election crisis: Jonathan should start healing process Marc Wabara. ThisDay Newspaper, p. 16.

The Nation editorial (April, 28, 2011). Post presidential election violence: A failure of leadership. The Nation, p. 22.

The Nation editorial (May 22, 2011).Post-election killing. The Nation, p. 13.

Ugah, N. (May1, 2011). Group lauds INEC, condemns post-election violence. Thisday Newspaper, p. 10.

Yusuf, N. (May 23, 2011). Bad leadership responsible for Nigeria's credibility crises. The Nation, p. 18. 